\title{
Study on The Implementation of Environmental School Through Adiwiyata School Program on High School in The Halal Tourism Spots of East Lombok District
}

\author{
*Yuri Windayani ${ }^{1)}$ and Surtani ${ }^{2)}$ \\ 1) Master Program Student of Geography Education Faculty of Social Science, Universitas Negeri Padang, \\ INDONESIA \\ 2) Department of Geography, Universitas Negeri Padang, INDONESIA
}

Email: yuriwindayani@yahoo.com

*Corresponding Author, Received: February 17, 2018, Revised: April 25, 2018, Accepted: May 01, 2018

This is an open acces article distributed under the Creative Commons 4.0 Attribution License, wich permits unregtricted use, Distribution, and reproduction in any medium provided the original work is properly cited @2017 by author and Universitas Negeri Padang

\begin{abstract}
This study aims to analyze the study of the application of environmental schools through adiwiyata school program in high school in district of East Lombok. This type of research is qualitative. The subjects of this study were principals, teachers, and students. Research took place at SMAN 1 Montonggading and SMAN 1 Sambelia. Technique of collecting data through interview, observation, and also documentation. Data analysis used was data reduction, data presentation (display data), and conclusion. The results of this study indicated that: (1) in the aspect of the school's environment-oriented School Policy, there is no policy from the local government that the school is eligible to be an environmentally sound school (adiwiyata). (2) on the aspect of environmental-based curriculum content at the school there is no specific subject of PLH. (3) on the aspect of participative participatory environmental protection activities, there are several activities that support the development of environmental activities in SMA of East Lombok district based on participative. (4) on the aspect of school management in environmental management, it is still not maximal, (5). in the aspect of obstacles to the application of environmentally sound schools is the lack of understanding and knowledge of school residents about environmental education, cost and community support. (6). in the aspect of policy priorities that emerged in the changes is expected to analyze the obstacles in implementing environmental schools through the program of school adiwiyata through planning of learning tools by teachers compiled into the subjects of geography by integrating the maximum environmental values, the School makes environmental education as a optional subject, Development of geography teacher's knowledge and skills in collaboration with environmental agencies on environmental schools, and given understanding to the public about the importance of environmental education.
\end{abstract}

Keywords: Adiwiyata School Program, Halal Tourism Spot

\section{Introduction}

Education in Indonesia is one of the main priorities of the government. This has been explained in the Preamble of the 1945 Constitution. For, making the advanced country that needed qualified human resources by putting forward its education system. Education has many benefits, one of which is supporting earth saving activities and environmental management. The Government of Indonesia makes a policy that is applied in the educational world listed in Article 65 of the fourth point of Law Number 32 Year 2009 on Environmental 
Protection and Management. Where in the article explains that "everyone has the right and role in environmental management". From this statement the government which in this case is the educational institution is intended to participate in implementing environmental management through the declaration of Adiwiyata school program. Adiwiyata applied in the world of education was because of the belief that in the world of education it is easier to learn and apply all science and various norms and ethics to achieve the ideals of sustainable development (Dwi Rahma Yanti, et.al. 2014).

According to Adiwiyata's Guide (2011) there are 1,351 schools from 251,415 schools (SD, SMP, SMA, SMK) throughout Indonesia, which have 56 independent Adiwiyata schools, 113 Adiwiyata schools, 103 Adiwiyata candidates, or total Adiwiyata award reached 272 Schools (SD, SMP, SMA, SMK) all over Indonesia. In Indonesia, the adiwiyata school must meet four components: 1) Environmental Based Policy, 2) Implementation of Environment-Based Curriculum, 3) Participation Based Environmental Activities and 4) Management of Environmentally Friendly Facilities (MoE, 2011). At senior high schools in East Lombok district of West Nusa Tenggara province, there are some schools whose school management on the one hand can display contradictory conditions when viewed from the point of environmental conservation. This is characterized by the behavior of teachers and school students who are not environmentally sound. Supported environmental facilities and infrastructures are disregarded with the principles of environmental conservation such as massive school field construction that reduces the extent of water catchment areas, negative environmental hygiene behaviors such as various forms of pollution / waste disposal, vandalism to the object of the built environment with a culture of "less conscious of the environment". However, there are already some schools that have realized some actions, such as changing the school environment has been changed into a beautiful environment to support the preservation of the environment by planting shady trees in the school yard. In addition, the school also designed a means of activities to support the implementation of Adiwiyata program, which includes the construction of green house, greenery surrounding environment, biophori use, electricity savings. In preparing the implementation of Environment-Based Curriculum, the school also insert subjects on Environmental Education (PLH).

According to Zsoka et al., (2013); Hermon (2014), knowledge of environmental means knowledge and awareness about environmental issues and solutions. The integration of environmental education into the school program is expected to become a process of habituation so that the expected development of behavior, attitude of students to appreciate, love and maintain the environment that can become a daily habit (Surahkusuma, 2010 in Maisyarotul, 2010). School preparation within the Environmental Policy component includes, among other things, a program for environmental protection and management within the School Budget Activity Plan (RKAS). The budget is allocated proportionally to activities such as student activities, curriculum, capacity building of educators and educators and education personnel, facilities and infrastructure, culture and school environment, improvement and development of quality (KLH, 2012). Looking at the environmental management issues, the government is committed to maintaining the environment

\section{Method}

The type of research used in this study is qualitative. The research was conducted in the district of East Lombok. The subjects of this study were principals, teachers, and students in SMAN 1 Montonggading and SMAN 1 Sambelia East Lombok. Informants of research were taken by Purposive Sampling (purposive sample) that is sample research based on certain characteristic (Sugiono, 2013). Data collection techniques used in this study are observation, interview and documentation study. Data analysis techniques used with qualitative analysis techniques are data reduction, data presentation and conclusion drawing. Furthermore, in analyzing the obstacles that exist in the application of environmentally sound schools in SMAN Kabupaten Lombok Timur, it is necessary for the expected changes. Policy priorities can be made using Interpretative Structural Modeling (ISM). ISM is a tool used to analyze and interpret the relationship between obstacles (Deepak Singhal, et.al., 2018). The researchers chose this approach because the benefits, direct and indirect relationships between variables based on the situation revealed are much more accurate than the individual factors taken separately (Cagno et al., 2014; Hermon, 2017). Policy priorities that arise in expected changes to analyze barriers in applying environmentally sound schools through adiwiyata programs in East lombok High School using ISM. The research was carried out by the following stages: (1) Conducting traces of information sources that can illustrate the boundaries, subject matter, developments and problems in the sub-sector of the 
prasahan, territorial understanding, strategic management understanding, and then define the objective formulation as the direction of research implementation . (2) Conducting expert surveys to review and define the elements / sub elements related to the agro-industry real estate livestock development strategy, determine the type of agroindustry selected as the object of the study of the development system. (3) Designing a system of structuring by undertaking the study / determination of key elements of development, with Interpretative Structural Modeling (ISM). (Dharmaputra, Arie Mirah, 2014) The steps in the ISM-VAXO technique are: 1. Structural Self-Interaction Matrix - VAXO (SSIM-VAXO) 2. SSIM-VAXO transformation into Reachability Matrix (RM) binary number 3. Transitive matrix testing 4. Sub-element classification based on Driver Power (DP) and Dependence (D) 5. Preparation of hierarchy based on sub-element rankings.

Table 1. Contextual Relationship Symbols and Definitions Between ISM-VAXO Elements

\begin{tabular}{ll}
\hline $\begin{array}{l}\text { Symbol of tual context relationships between } \\
\text { elements }\end{array}$ & Definition of contextual relationships between elements \\
\hline $\mathrm{V}$ & Element $\mathrm{E}$ causes a contextual relationship with $\mathrm{E}$ but not vice versa $\ldots(\mathrm{E}=1$ and \\
& $\mathrm{E}=0)$ \\
$\mathrm{A}$ & $\mathrm{A}$ Element $\mathrm{E}$ causes a contextual relationship with $\mathrm{E}$ but not vice versa .... $(\mathrm{E}=0$ \\
$\mathrm{X}$ & and $\mathrm{E}=1)$ \\
$\mathrm{X}$ & Elements $\mathrm{E}$ and $\mathrm{E}$ cause mutually contextual relationships .......................... $(\mathrm{E}=$ \\
$\mathrm{O}$ & 1 and $\mathrm{E}=1)$ \\
& $\mathrm{O}$ Elements $\mathrm{E}$ and $\mathrm{E}$ and vice versa, does not cause a contextual relationship \\
\hline
\end{tabular}

Source: Dewata dan Iswandi (2017)

\section{Results and Discussion}

East Lombok regency is located on the eastern tip of the island of Lombok with astronomical location between 1160 - 1170 East Longitude and 80 - 90 South Latitude, East Lombok regency has a long coastline, considering most of its territory is adjacent to the waters. It is adjacent to Java Sea in the north, Alas Strait in the east, Indonesia Ocean in the east, Central Lombok and North Lombok regency in the west. East Lombok regency is a district that has an area of $1605.55 \mathrm{~km} 2$. From several schools in East Lombok, obtained 2 schools that approached with halal tourist attraction in East Lombok is SMAN 1 Montonggading and SMA 1 Sambellia.

1. Environmental school policy

Viewed from the aspect of the school's environmentally sound policy, there is no policy from the local government that the school is fit to be an environmentally sound school (adiwiyata). At SMAN 1 Montonggading, located in a beautiful and cool village in a school environment, the residents of the school planted alive pharmacies and protective plants in the school yard area. The school looks beautiful and green, as well as SMA 1 Sembelia located near the beach. In the field of education, the government has enacted the adiwiyata program as an environmental processing effort through the education field. This matter is poured in Regulation of State Minister of Environment no. 02 of 2009 on the guidance of the implementation of the adiwiyata program. However, the adiwiyata program only emphasizes on environmental management and not yet at the disaster mitigation stage, considering Indonesia is a country prone to disaster. UU no. 32 year 2009 on the protection and management of the environment, especially article 65 paragraph 2 that one of the rights of the community is to get an environmental education. Schools that care and culture the environment will create policies in the effort to protect the environment. A school that uses environmentally friendly means of infrastructure will create healthy environmental conditions, conducive to learning and energy saving. In addition, a caring and cultured school environment will reduce the impact of environmental damage through wise maintenance and environmental management in accordance with its procedures (Zhang Juan, 2009). Implementation of Adiwiyata school program has the criteria seen from the components and standards. Components include: (1) Environmentally sound policies and school activities and budget plans which are applied within the scope of the school in the form of vision, mission and objectives of the school contain environmental protection and management, (2) Implementation of environment-based curriculum where teachers or educators are competent so that in the 
delivery of environmental learning can be understood and implemented by learners, (3) Participatory based environmental protection activities, (4) Management of environmentally friendly support facilities which in the provision of infrastructure facilities such as paving block, green open space or green house, and recycling places. School management in hand can show contradictory conditions when viewed from an environmental point of view. Environment-oriented school policies in East Lombok district based on interviews with principals in SMA 1 Montonggading and SMA 1 Sambelia. Implementation of school policies to build an environmental culture still requires socialization efforts.

\section{Environmental-based curriculum}

There are no special PLH subjects. PLH material is inserted in various chapters on several subjects (subject), especially geography and some incidental activities, such as Earth Day commemoration, Water Day, and so on. The PLH model is used as a local content (optional subject), for example the subject which is added as a school or local government initiative other than the other specified subject. In terms of cleanliness of the school held an activity every morning before entering the class of students picked up the garbage that exist in the school environment. But according to an interview with one of the teachers, he said that the school has not been school environmentally friendly (adiwiyata) when the school is supposed to be school environmentally sound. This is due to the knowledge and skills of environmental maintenance and environmental care has never been given to school residents in depth that clearly the school has been categorized environmentally sound schools (adiwiyata) supported from the environment.

3. Participatory based environmental protection activities

There is lack of school ability in identifying environmental issues, student perceptions, teachers. It is seen from the interview from a teacher in SMA 1 Sembalia, that the environmental knowledge is very less and activities that support the environment are not held in school. It was because of the lack of the school's ability to provide socialization and knowledge to the students in the school. However, there are some activities that support the development of environmental activities in SMA East Lombok Regency based on participative among others: a) Maintain and keep the building and school environment by the citizens of the school are visible from every class that already has a clean daily schedule, the program "gerebek sampah" and "Cleansing Balad Kuring" and Hygiene Competition which is conducted once every 1 month, b) Utilizing the land and school facilities according to the rules of protection and management of LH such as park in every class, living pharmacy, green house, fish pond and waste management in the form of composting and garbage bank, c) The existence of creativity and innovation of the school community in the effort of environmental protection and management, the activities are recycling of garbage, water utilization, artwork and energy saving d) Enhancing the role of school committee in building partnership for environmental learning .

4. School managers in environmental management

Still not maximally only limited to passive participants and have not received adequate space in environmental management activities, The condition of school facilities and infrastructure that support the care and environmental conscious movement has not shown optimal efforts and still requires a great effort to make it happen. The results of this study will then be useful as an inventory of preliminary data for regional education planning programs in the development of sustainable human resources. Environmental facilities and infrastructure developed are not planned based on environmental preservation principles such as large school and construction that minimizes water catchment levels, nagative environmental hygiene behaviors such as various forms of pollution / waste disposal, and vandalism against the developed environment.

5. Barriers To the application of environmentally sound schools

Efforts are made, on the application of environmentally sound schools in the beginning by doing the main activities on the program Adiwiyata to realize the school cares and cultured environment. In addition, the program also develops basic norms such as togetherness, openness, equality, honesty, fairness, and environmental sustainability. The Adiwiyata Program aims to create good conditions for schools to be a place of learning and awareness of schoolchildren (teachers, pupils and school employees) so that in the future the school's citizens can take responsibility in the efforts to save the environment. In implementing the implementation of environment-oriented schools so far, in the SMA Negeri in the district of East 
Lombok are still encountered various situation problems that hinder the implementation of Adiwiyata school are: (1) Knowledge and understanding of the school community about the concept of environmentally sound schools. One of the obstacles seen from the results of interviews with one of the teachers in high school district of East Lombok is the teacher in teaching looks less variation in developing and less linking the subject matter of the environment on related subjects, so the delivery to students is still less understandable, and teachers are less able to provide the delivery of material with new things that can be associated with the environment around the school. On the other hand there is a group of students who are still not aware in understanding the concept of environmentally sound schools. This is in accordance with the opinions of other informants who said there are still a group of students who still ignore the importance of protecting the environment with actions that are not preserving the environment, (2) Cost / funding issues. In the opinion of informants that there is still lack of facilities and facilities that support environmentally sound schools due to lack of funds obtained, (3) Support community and other agencies that are still low. Adiwiyata award is given as a form of appreciation to schools that are able to carry out efforts to improve environmental education properly, in accordance with predetermined criteria. The award is given at the stage of empowerment (over a period of less than 3 years) and independence stage (over a period of more than 3 years). Implementation to realize a caring and cultured school environment, school residents need to be involved in various environmental learning activities. In addition, the school is also expected to involve in surrounding communities in conducting various activities that provide benefits both for the citizens of the school, community and environment. But in practice there are still these obstacles, such as the opinion of informants who say that the community has little role in implementing environmental education. In addition, other informants' opinions of the obstacles that occurred at SMAN in East Lombok district such as school principals and school representatives are persistent in improving environmentally sound schools but lack of knowledge of teachers and students about the importance of implementing environmentally sound schools, (4) Policy priorities emerging in expected changes to analyze barriers in applying environmentally sound schools. Various obstacles in applying environmentally sound schools are faced nowadays are there are still schools in Eastern Lombok Regency that deserve to get adiwiyata school in terms of its existing facilities and infrastructure, after interviewing various elements and sub elements of change are expected to analyze the obstacles in applying environmentally sound schools, it is stipulated as follows:

Table 2. Elements and Sub Elements of An Environmentally Sound School

\begin{tabular}{|c|c|}
\hline Element & Sub Element \\
\hline Planning & $\begin{array}{l}\text { 1. Planning of learning tools by teachers compiled into the subjects of geography by integrating } \\
\text { the values of the environment to the maximum } \\
\text { 2. Improvement of facilities of infrastructure that support environmentally sound schools } \\
\text { 3. Increased costs in limited funds } \\
\text { 4. Planning by the principal by creating an adiwiyata school program that can be seen from the } \\
\text { competition activities on the environment } \\
\text { 5. Schools should have references that are a condition of environmentally sound schools issued } \\
\text { by the environmental agency } \\
\text { 6. Schools make environmental education a mulok }\end{array}$ \\
\hline Implementation & $\begin{array}{l}\text { 1. Development of geography teacher knowledge and skills in collaboration with environmental } \\
\text { agencies on environmentally sound schools } \\
\text { 2. Development of students' knowledge in environmental education for the application of } \\
\text { environmentally sound schools } \\
\text { 3. Provided understanding to the public about the importance of environmental education }\end{array}$ \\
\hline
\end{tabular}

Based on the results of expert review, 9 sub elements are defined which have strong interaction with expected changes to analyze barriers in applying environmentally sound schools through adiwiyata program. 9 sub elements are then analyzed level of interaction with ISM technique. The first stage is to study the contextual relationship in the form of SSIM-VAXO Matrix as in Figure 1. 


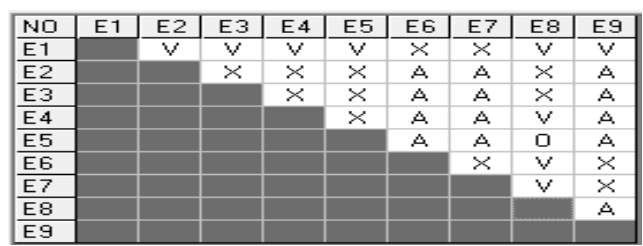

Figure 1. SSIM-VAXO matrix elements of environmental implementation are environmentally sound

The elements of change that are expected to analyze barriers in applying environmentally sound schools include:

1. The planning of learning tools by teachers is arranged into geography subjects by integrating the maximum environmental values

2. Improvement of facilities of infrastructure that support environmentally sound schools

3. Increased costs in limited funds

4. Planning by the principal by creating an adiwiyata school program that can be seen from the competition activities on the environment

5. Schools should have references that are a condition of environmentally sound schools issued by the environmental agency

6. Schools make environmental education a mulok

7. Development of geography teacher knowledge and skills in collaboration with environmental agencies on environmentally sound schools

8. Development of students' knowledge in environmental education for the application of environmentally sound schools

9. Provided understanding to the public about the importance of environmental education

The second stage is to transform the SSIM-VAXO into a Reachability Matrix (RM) binary number, then proceed to the third stage of transitive testing of the consistency in RM to obtain the final RM Matrix as shown in Table 3.

Table 3. Results of the final Reachability Matrix of the Implementation Element

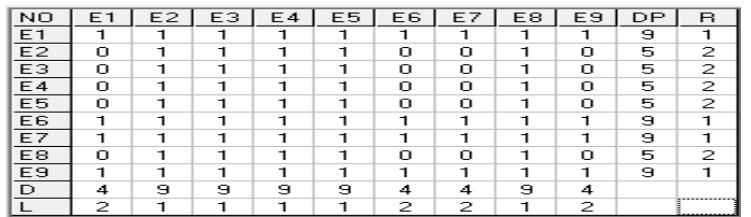

In Table 3, it can be seen that Sub elements 1,6,7, and 9 are planning of learning tools by teachers arranged into geography subjects by integrating maximum environmental values, schools make Schools make environmental education as mulok, knowledge development and geography teacher skills in collaboration with environmental agencies on environmentally sound schools, and given the public understanding of the importance of environmental education at the number one ranking with the largest value of Driver Power (DP) supported by the smallest Dependence - D. The fourth stage is the mapping of RM results in Table 2, to the Sub-element classification based on Driver Power (DP) and Dependence (D) as in Figure 2: 


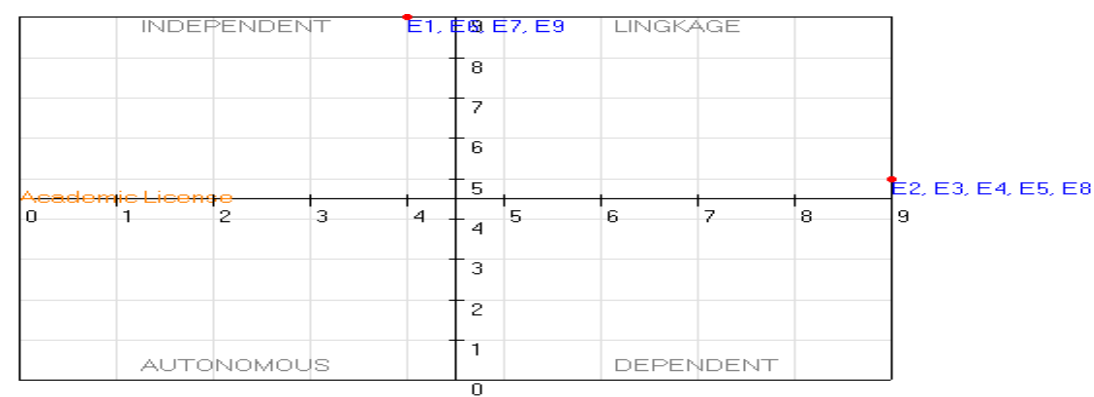

Figure 2. Classification Diagram of the Sub-Element of the Application of Environmentally Sound Schools

The classification of sub-elements is classified into 4 sectors:

Sector 1: Weak driver-weak dependent variables (Autonomous). The relationship of variables in this sector to the system is relatively small or unrelated.Sector 2: Weak driver-strongly dependent variables (Dependent). The variables in this sector depend on inputs and actions given to the system, especially from the linkage variables. Sector 3: Strong driver-strongly dependent variables (Linkage). The relationship between variables in this sector is unstable. Any action on that variable will have an impact on other variables. Sector 4: Strong driver-weak dependent variables (Independent). The variables in this sector are called free variables whose elements / sub elements can be considered as key factors of the system. (Dharmaputra, Arie Mirah, 2014). In the final stages is the preparation of sub-element hierarchy based on DP and D rank values. The results of the study place the overall sub-element of expected change to analyze barriers in applying environmentally sound schools as shown in Figure 3.

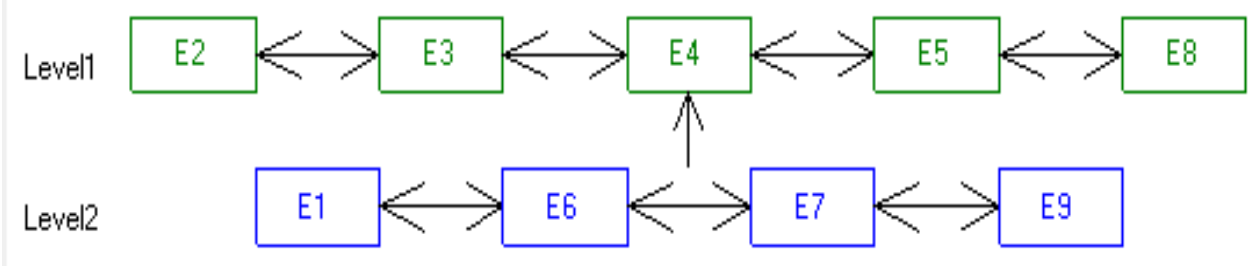

Figure 3. The Hierarchical Structure of Sub-Elements of the School Application of Environmental Insight

Based on the hierarchical structure there are 2 levels. The highest levels will have the greatest impact and have the highest involvement to analyze barriers in implementing environmentally sound schools in SMAN sub elements 1,6,7 and 8 have the greatest involvement in the application of environmentally sound schools.

\section{Conclusion}

From the results of the discussion can be concluded that the policy on environmental protection and management made by the government through education will be done well and achieve the Adiwiyata award. However, in high school district of East Lombok in the implementation of Adiwiyata school program experienced obstacles which lack of knowledge and skills about environmental management and environmental maintenance. So that the school residents have not received attention from the government to run the activities of environmental management and protection and the absence of government policies for schools in the area of halal tourism destination East Lombok Regency. Expert review results have identified a number of 9 sub elements that qualitatively determine the barriers in applying environmentally sound schools in SMAN East Lombok. Interaction behavior between sub elements has been analyzed using Interpretative Structural Modeling (ISM) method with ISM-VAXO technique. This method has been able to classify the 
entire sub elements into quadrants based on the value of Drive Power and Dependence and in the hierarchy structure based on Rank and Level, which then informs the key sub-elements namely: Teacher learning tool planning is compiled into geography subjects by integrating values (6), Development of knowledge and skills of geography teachers in cooperation with environmental agencies on environmentally sound schools (7), and given understanding to the public about the importance of environmental education life (8).

\section{References}

Attri, R. D and N. Sharma. (2013). Interpretive Structural Modeling (ISM) approach : an overview. Res. J. Manag. Sci.2(2),3-8.

Buku Panduan Adiwiyata. (2011). Panduan Adiwiyata. [internet] available from <http://panduan.adiwiyata.com> (accessed: 29 November 2017).

Cagno, E., Micheli, G.J.L., Jacinto, C., and Masi, D. (2014). An Interpretive Model of Occupational Safety Performance for Small-and Medium-Sized Enterprises. Int. J.Ind.Ergon. 44 (1), 60-74.

Dharmaputra, Arie Mirah. (2014). Penetapan Elemen Kunci Pengembangan Agroindustri Peternakan dengan Interpretative Structural Modeling (ISM). Jurnal. Universitas Sam Ratulangi Manado. ISSN 0852-2626.

Deepak, S,.Sushanta ,T ,.Sarat ,K,J,. Kaibalya ,K,N,. and Aishwarya, D. (2018). Interpretative Structural Modelling of Obtacles Hindering the Manufacturing Practices in India. ScienceDirect :ELSIVIELER

Dewata, Indang dan Iswandi U. (2017). Pendekatan Sistem. Depok : Raja Grafindo Persada

Dwi Rahmah, Yanti, et al., (2014). Implementasi Program Sekolah Adiwiyata (Studi pada SDN Manukan Kulon III/540 Kota Surabaya). Jurnal.Universitas Brawijaya. Vol. 2 No. 4

Hermon, D. (2014). Geografi Bencana Alam. Radjawali Press

Hermon, D. (2017). Climate Change Mitigation. Rajawali Pers (Radjagrafindo). Jakarta

Huril Aini, Maisyarotul. (2014). Penguasaan Konsep Lingkungan dan Sikap Peduli Lingkungan Siswa SMA Adiwiyata Mandiri di Kabupaten Mojokerto. Jurnal: UNESA

Kementerian Lingkungan Hidup dan Kementerian Pendidikan dan Kebudayaan. (2012). Panduan Adiwiyata: Sekolah Peduli dan Berbudaya Lingkungan. Jawa Tengah: Badan Lingkungan Hidup.

MoE. (2011). Guidelines for Adiwiyata: School which Care and Environment Cultured. Jakarta: Ministry of Environment and the Ministry of National Education of the Republic of Indonesia.

Peraturan Menteri Negara Lingkungan Hidup Nomor 05 Tahun 2013 tentang Pedoman Pelaksanaan Program Adiwiyata. Jakarta, Kementerian Lingkungan Hidup.

Sugiyono. (2013). Metode Penelitian Kuantitatif Kualitatif dan R\&D. Bandung, Alfabeta.

Triutomo, Sugeng. (2007). Pengembangan Wilayah Melalui Pembentukan Kawasan Ekonomi Terpadu dalam Tiga Pilar Pengembangan Wilayah, Jakarta: BPPT

Undang-Undang Nomor 32 Tahun 2009 tentang Perlindungan dan Pengelolaan Lingkungan Hidup. Jakarta, Kementerian Lingkungan Hidup.

Zhang, Juan. (2009). An Introduction of Building Green Schools. Journal of Suistainable Development Vol.2 (01):200-203. China: Applied Technology College, Xi’an Polytechnic University.

Zsoka, A., Szerenyi, Z. M., Szechy, A., \& Kocsis, T. (2013). Greening Due to Environmental Education Environmental Knowledge, Attitudes, Consumer Behavior and Everyday Pro Environmental Activities of Hungarian High School and University Students, Journal of Cleaner Production. 